\title{
Stem cell transplantation for myelopro- liferative diseases in the era of molecular therapy
}

\author{
Axel R. Zander \\ Huntsman Cancer Institute, University of Utah, USA
}

Professor Axel R. Zander, Huntsman Cancer Institute, University of Utah, 2000, Circle of Hope, Room 2166, Salt Lake City, UT 84112 USA

\section{Summary}

A sufficient part of allo-HSCT is now performed for myelodysplastic syndromes and myeloproliferative neoplasms (MPN), whereas chronic myeloid leukemia is mostly treated by tyrosine kinase inhibitors (TKI). In some special situations, the reasons for allo-SCT in CML are as follows: TKI toxicity; resistance to common drug therapy, and advanced disease (accelerated phase or blast crisis). However, an improvement in progression-free survival may be obtained in advanced CML after haploidentical allo-HSCT versus grafting from HLA-matched related/unrelated donors.

When planning therapy of primary myelofibrosis, one should take into account variable clinical course of the disease using, e.g., Lille scoring system which provides some prognostic criteria, molecular genetic markers, especially, overexpression of JAK2 gene thus allowing usage of ruxolitinib. Allo-SCT can cure myelofibrosis patients transformed to leukemia. In cases of relapse, a 2nd allo-HSCT or donor lymphocyte infusion may result into prolonged survival of the patients.

\section{Introduction}

At the present time, WHO Classification of Myeloid Neoplasms includes a range of myeloproliferative Neoplasms (MPN). Of them, most common are: (1) chronic myeloid leukemia (CML, BCR-ABL1+); (2) chronic neutrophilic leukemia (CNL); (3) polycythemia vera (PV); (4) primary myelofibrosis (PMF); (5) essential thrombocythemia (ET), mastocytosis. A group of myelodysplastic/myeloproliferative Neoplasms (MDS/MPN) includes chronic myelomonocytic leukemia (CMML); atypical CML (aCML, BCR-ABL1-); juvenile myelomonocytic leukemia (JMML). Some MDS/ MPN cases remain unclassifiable.

E-mail: axel.zander@hci.utah.edu

Results in chronic myelomonocytic leukemia patients treated with allo-HSCT depend on the pre-transplant risk scores. Patients transplanted in CR had significantly longer relapse-free survival and significantly longer overall survival. Early transplants were associated with higher survival rates. In cases of atypical CML, early allogeneic transplant should be performed. Allo-SCT is a method of choice in advanced systemic mastocytosis. It is performed in cases associated with non-mast cell involvement; in aggressive systemic mastocytosis, and in mast cell leukemia.

\section{Keywords}

Myeloproliferative disorders, allogeneic hematopoietic stem cell transplantation, tyrosine kinase inhibitors, chronic myeloid leukemia, primary myelofibrosis, chronic myelomyelocytic leukemia, systemic mastocytosis. 


\section{Current strategies of CML treatment}

Previously, allo-HSCT was the only curative treatment for CML, and CML was the most frequent indication for Allo SCT. With Imatinib, TKI became the frontline therapy for newly diagnosed CML. E.g. the IRIS Program "International Randomized Study of Interferon and STI571", has demonstrated superiority of Imatinib versus interferon treatment in CML therapy [2]. Therefore, transplant activities in this field dropped quickly, and allo-SCT moved from frontline to second, third-line therapy. In some special situations, the reasons for allo-SCT are as follows: TKI toxicity; resistance to common drug therapy, and advanced disease (accelerated phase or blast crisis, $\mathrm{BC}$ ).

Efficiency of allogeneic HSCT (Allo SCT) in chronic myeloid leukemia in the Imatinib era was evaluated in a subgroup of the Randomized German CML Study IV. Appropriate survival probability was evaluated showing that the patients with elective allo-SCT in first CP ( $\mathrm{n}=20$; group I) and those who underwent transplantation after Imatinib failure in first CP ( $n=36$; group II) had a comparable 3-year survival probability of $88 \%$ and $94 \%$, respectively (CI: 69.3-98.7 and 83.9-99.4). The patients who underwent transplantation in advanced disease $(n=28$; group III) had a 3-year survival probability of only 59\% (CI: 38.6-77.5). Matched pair analysis for 53 patients who underwent transplantation compared to 106 matched Imatinib-treated patients also did not show any differences thus suggesting similar efficiency of the both treatment strategies [3].

Management of CML blast crisis and TKI usage could be dependent on some proven facts [4]:

- TKI moderately improves OS median survival for $<1$ year.

- Choice of TKI should be directed by mutational profile.

- Best prognosis is suggested in patients who achieve $2^{\text {nd }} C P$.

- In general, allo-SCT improved survival.
As shown by Hehlmann et al [4], the CML IV study with Imatinib treatment in patients with blast crisis CML has shown a survival of ca. $20 \%$ over 10 years, as compared to $<5 \%$ survival in pre-Imatinib era. Distinct improvement in OS and event-free survival (EFS) was shown in BC CML patients when using combination of allo-SCT and TKIs compared to only TKIs. E.g., the median OS in the TKI+allo-HSCT group (20 months, 95\% CI 1-74 months) was significantly longer than that in the TKIs group (4.5 months; 95\% CI 3.55.5 months). Similarly, the 4 -year OS rates in the TKIs+allo-HSCT group were significantly higher than those in the TKI group ( 50.0 vs $10.0 \%, P=0.016$ ). (b) The median EFS in the TKIs+allo-HSCT group (18 months, 95\% CI 1-72.7 months) was also significantly longer than in the TKIs group (3 months; 95\% CI 1.9-4.0 months). The 4-year EFS rates in the TKIs+allo-HSCT group were significantly higher than those in the TKIs group ( 50.0 vs $10.0 \%, \mathrm{P}=0.002$ ) (Jiang $\mathrm{H}$ 2014). It should be noted that $2 / 3$ of the donors were haploidentical.

Improved progression-free survival (up to 60\%) was registered in the patients with advanced CML after haploidentical allo-HSCT versus grafting from HLA-matched related/unrelated donors [5]. Thus, the donor type may influence survival for transplanted patients with advanced CML.

\section{Primary Myelofibrosis}

To take into account variable clinical course of a myeloproliferative disorder, the Lille scoring system provides some prognostic criteria, as mentioned:

- The "low" group (Hb-level > $10 \mathrm{~g} / \mathrm{dL}$ and WBC between 4 and $30 / \mathrm{nL}$ (median OS 93 months);

- The "intermediate" group (Hb-level $<10 \mathrm{~g} / \mathrm{dL}$ or

WBC $>30 /<4 \mathrm{~nL}$ (median OS 26 months);

- The "high" group (Hb-level $<10 \mathrm{~g} / \mathrm{dL}$ and $\mathrm{WBC}<4 / \mathrm{nL}$ or $>30$ /nL (median OS 13 months).

Table 1. Summary of IPSS criteria

\begin{tabular}{|c|c|c|c|}
\hline Risk Model & Risk Factor & Risk Stratification & Median Survival (months) \\
\hline Dynamic IPSS & $\begin{array}{l}\text { Age }>65 \text { years } \\
\mathrm{HgB}<10 \mathrm{~g} / \mathrm{dL}(2 \mathrm{pts}) \\
\text { WBC }>25 \times 10^{9} / \mathrm{L} \\
\text { Circulating blasts } \geq 1 \% \\
\text { Constitutional symptoms }\end{array}$ & $\begin{array}{lc}\text { Low: } & 0 \\
\text { Intermed-1: } & 1-2 \\
\text { Intermed-2: } & 3-4 \\
\text { High: } & 5-6\end{array}$ & $\begin{array}{l}\text { Not reached } \\
118 \\
58 \\
27\end{array}$ \\
\hline DIPSS-Plus & $\begin{array}{l}\text { DIPSS Risk + } \\
\text { Platelet }<100 \times 10^{9} / \mathrm{L} \\
\text { Unfavorable cytogenetics } \\
\text { Transfusion requirement }\end{array}$ & $\begin{array}{lc}\text { Low: } & 0 \\
\text { Intermed-1: } & 1 \\
\text { Intermed-2: } & 2-3 \\
\text { High: } & 4-6\end{array}$ & $\begin{array}{l}180 \\
80 \\
35 \\
16\end{array}$ \\
\hline
\end{tabular}


Table 2. Clinical outcomes of reduced-intensity conditioning (RIC) regimens in MF patients

\begin{tabular}{|l|l|l|l|l|}
\hline Authors & $\mathbf{n}$ & Median age & NRM & 05 \\
\hline $\begin{array}{l}\text { Rondelli et al. } \\
2005\end{array}$ & $\mathrm{n}=21$ & 54 yrs & $10 \%(1 \mathrm{yr})$ & $85 \%(2.5 \mathrm{yrs})$ \\
\hline $\begin{array}{l}\text { Kröger et al. } \\
2005\end{array}$ & $\mathrm{n}=21$ & 53 yrs & $16 \%(1 \mathrm{yr})$ & $84 \%$ (3yrs) \\
\hline $\begin{array}{l}\text { Bacigalupo et al. } \\
2010\end{array}$ & $\mathrm{n}=46$ & 51 yrs & $24 \%(5 \mathrm{yrs})$ & $45 \%(5 \mathrm{yrs})$ \\
\hline $\begin{array}{l}\text { Kröger et al. } \\
\text { EBMT 2009 }\end{array}$ & $\mathrm{n}=103$ & 55 yrs & $17 \%(1 \mathrm{yr})$ & $67 \%$ (5yrs) \\
\hline
\end{tabular}

Reduced conditioning regimen when transplanting the MF patients yielded good results in terms of non-relapse-related mortality (NRM) and OS levels (Table 2).

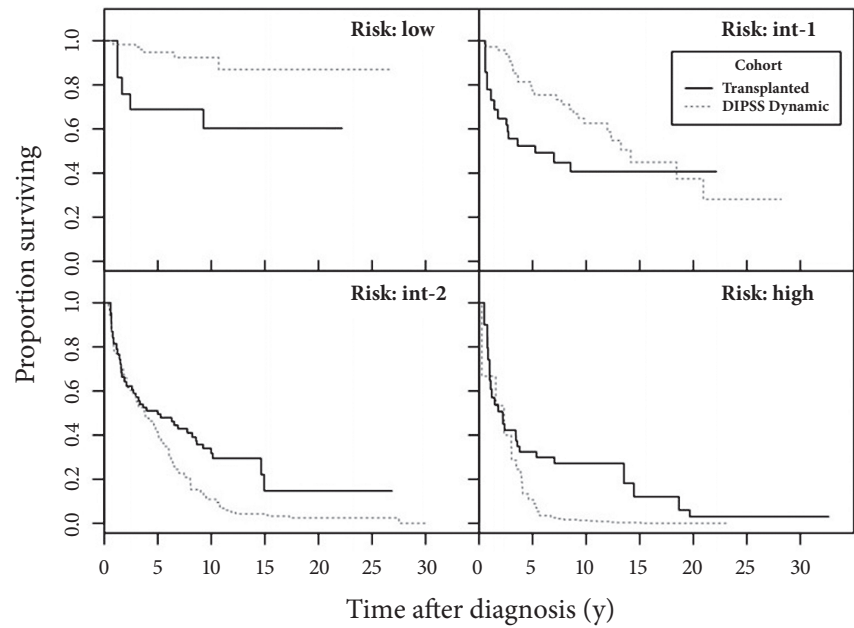

Figure 1. Survival probabilities for the 4 risk subgroups in MF (DIPSS risk: low, int-1, int-2, high). DIPSS score is taken at stem cell transplant (solid, transplant cohort) or at the indicated time (dotted, nontransplant cohort). Time (horizontal axis) elapses from diagnosis [10].

Efficiency of SCT proved to depend on initial risk score, e.g., assessed by DIPSS. As seen from Fig. 1, SCT in advanced disease prolongs survival in high-risk patients.

Allogeneic SCT option for myelofibrosis with leukemic transformation was evaluated in EBMT study. This involved 1048 cases in allo SCT; 46 patients, with leukemic transformation [11]. The cumulative incidence of treatment-related mortality at 1 year was $28 \%$, and of relapse at 3 years was $47 \%$. The 3-year progression-free (PFS) and overall survival (OS) rates were $26 \%$ and $33 \%$, respectively. Hence, allogeneic SCT can cure myelofibrosis patients transformed to leukemia.

Molecular genetic markers, i.e., multiple gene expression profile of leukemic cells may be predictive for the outcome in myelofibrosis patients after allogeneic transplantation, especially overexpression of JAK2 and ASXL1 gene, as shown by Kröger et al. [12].
Our previous studies concerned treatment of the myelofibrosis patients who relapsed after first allo-SCT [13]. The following treatment consisted of either donor lymphocyte infusions, or second allo-SCT from an alternative donor. A group of 30 patients with relapsed myelofibrosis treated by donor lymphocyte infusions and/or second allo-SCT showed good 5-year overall survival rates. I.e., $2^{\text {nd }}$ SCT caused complete remission in 14 out of 17 patients (82\%).

Ruxolitinib, a JAK2 inhibitor, is a promising therapeutic option for MF patients during peritransplant period [14]. Feasibility and safety of Ruxolitinib treatment was tested in Hamburg-Eppendorf clinic and Ruxolitinib was used in 12 patients at a dose of $10+10 \mathrm{mg}$. Severe GVHD was observed only in 1 case of 12; overall survival was 100\% after short follow-up (a mean of 163 days) [15].

\section{Chronic Myelomonocytic Leukemia (CMML)}

CMML is another chronic myeloproliferative disorder. Different prognostic scores for CMML were developed in MD Anderson, Mayo Clinics, a Düsseldorf scoring etc. CMML-specific prognostic scoring system was the subject to external validation being tested in 578 patients, as seen from Table 3.

Progression-free survival (PFS) in CMML was assessed by a group from the MD Anderson Cancer Center [17]. The study was performed in $83 \mathrm{CMML}$ patients. In 78 cases a pre-transplant induction treatment was applied, with 37 patients receiving hypomethylating agents and cytotoxic chemotherapy in 41 cases. Patients treated with a hypomethylating agent had a lower cumulative incidence of relapse at 3 years post-transplant (22\%) than those treated with other agents (35\%; $\mathrm{P}=.03)$, improved progression-free survival (PFS), with no detectable difference in treatment-related mortality at 1 year post-HST. In summary, their data support the value of hypomethylating agents administered before allo-SCT, in order to achieve morphologic remission.

Results in CMML patients treated with allo-HSCT depend on the pre-transplant risk scores (HCT-specific CPSS), as shown by IBMTR group in 209 patients [16]. I.e., adjusted disease-free survival, starting at the time of transplant, at a median follow-up of 51 months. CPSS score, Karnofsky per- 
Table 3. Prognostic scales in CMML, a summary of different studies [16]

\begin{tabular}{|c|c|c|c|}
\hline Scoring System & No. Patients & $\begin{array}{l}\text { External } \\
\text { Validation }\end{array}$ & Variables Included in Final Scoring System \\
\hline $\begin{array}{l}\text { MD Anderson } \\
\text { prognostic score }\end{array}$ & 213 & No & $\begin{array}{l}\text { 1. Hemoglobin }<12 \mathrm{~g} / \mathrm{dL} \\
\text { 2. Circulating immature myeloid cells } \\
\text { 3. Absolute lymphocyte count }>2.5 \times 10^{9} / \mathrm{I} \\
\text { 4. BM blasts } \geq 10 \%\end{array}$ \\
\hline Dusseldorf score & 288 & No & $\begin{array}{l}\text { 1. BM blasts } \geq 5 \% \\
\text { 2. } \mathrm{LDH}>200 \mathrm{u} / \mathrm{l} \\
\text { 3. Hemoglobin } \leq 9 \mathrm{~g} / \mathrm{dL} \\
\text { 4. Platelets } \leq 100 \times 10^{9} / \mathrm{l}\end{array}$ \\
\hline $\begin{array}{l}\text { Spanish cytoge- } \\
\text { netic risk stratifi- } \\
\text { cation system }\end{array}$ & 414 & No & $\begin{array}{l}\text { 1. Low risk: normal karyotype or loss of } Y \text { chromosome as single anomaly } \\
\text { 2. High risk: presence of trisomy } 8 \text { or abnormalities of chromosome } 7 \text {, or } \\
\text { complex karyotype } \\
\text { 3. Intermediate risk: all other abnormalities }\end{array}$ \\
\hline $\begin{array}{l}\text { CMML-specific } \\
\text { prognostic } \\
\text { scoring system }\end{array}$ & 578 & Yes & $\begin{array}{l}\text { 1. CMML FAB type } \\
\text { 2. CMML WHO type } \\
\text { 3. CMML-specific cytogenetics* } \\
\text { 4. RBC transfusion dependence }\end{array}$ \\
\hline $\begin{array}{l}\text { Mayo prognostic } \\
\text { model }\end{array}$ & 226 & Yes & $\begin{array}{l}\text { 1. Absolute monocyte count }>10 \times 10^{9} / \mathrm{I} \\
\text { 2. Presence of circulating blasts } \\
\text { 3. Hemoglobin }<10 \mathrm{~g} / \mathrm{dL} \\
\text { 4. Platelet count }<100 \times 10^{9} / \mathrm{I}\end{array}$ \\
\hline
\end{tabular}

formance status, and graft source proved to be significant predictors of survival. The patients with intermediate-2/high risk had a nearly 2 -fold increased risk of death after relapse compared to those with low/intermediate-1 CPSS scores.

An EBMT study of relapse-free survival (left) and overall survival (right) according to disease stage (CR versus no-CR) at transplantation was performed in a group of 513 CMML patients The subjects transplanted in CR had lower probability for non-relapse death $(\mathrm{P}=0.002)$ and longer relapse-free and OS ( $\mathrm{P}=0.001$ and $\mathrm{P}=0.005$, respectively). In multivariate analysis the only significant prognostic factor for survival was the presence of $\mathrm{CR}$ at transplantation $(\mathrm{P}=0.005)$. Hence, patients transplanted in CR had significantly longer relapse-free survival and significantly longer overall survival [18].

Moreover, both RFS and OS differed according to transplantation within 12 months or after 12 months after diagnosis of CMML. Early transplant was associated with significantly higher survival rates.

\section{Systemic mastocytosis}

Systemic mastocytosis (SM) is a myeloproliferative disorder with clonal expansion of mast cell precursors in various organs [19]. It is a heterogeneous group by the clinical course and malignant precursor biology: it may indolent do not shorten life expectancy. Advanced SM may proceed as Mast Cell Leukemia (MCL), SM with associated hematologic nonmast cell lineage diseases, or aggressive systemic mastocytosis (ASM).
Survival rates from months to a few years despite cytoreductive therapy were not too high.

I.e., the 3-year OS and PFS in the total group of mastocytic malignancies are about $50-60 \%$ etc. [20]. Allo-SCT is a method of choice in advanced systemic mastocytosis. However, some somatic mutations predispose for inferior clinical outcome in this disorder, i.e., ASXL1 or CBL mutations (Fig. 2). These molecular markers comprise a distinct risk factor when treating ASM [21].

Atypical chronic myeloid leukemia (aCML) with BCR-ABL1-negativity is considered a special clinical entity characterized by leukocytosis, affected granulocyte myeloid precursors, dysgranulopoiesis, PH-negativity, SETBP1 expression. Mutated RAS was found in some cases (7/20 [35\%] vs $4 / 29$ [14\%]) and less JAK2p.V617F (3/42 [7\%] vs 10/52 [19\%]). Compared with unclassified MDS/MPN-U, patients with aCML showed a significant inferior OS (12.4 months, 95\% CI [9.0-16.1] vs 21.8 months, 95\% CI [17.6-28.8]) and ACL-free survival (11.2 months, 95\% CI [7.0-13.5] vs 18.9 months, $95 \%$ CI [12.3-26.3]), as reported by Wang et al. [22] .

Age- and risk-score dependent survival in atypical CML were assessed as five-year overall survival following allogeneic transplantation in 42 patients from an EBMT study [23]. As expected, the older age of aCML patients ( $<45$ years) was associated with sufficiently lower 5 -year survival $(<40 \%)$ as compared to younger patients. 

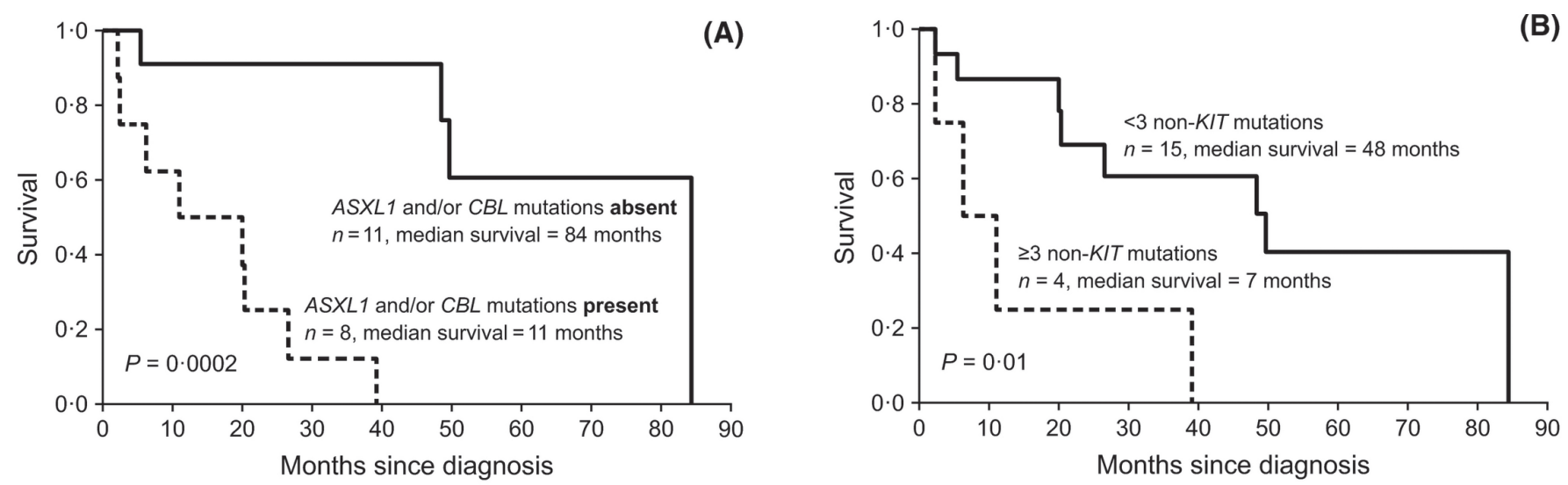

Figure 2. Molecular risk factors determine survival rates in systemis mastocytosis

\section{Summary}

As based on clinical experience and current multicentric studies, some recommendations may be given on WHOM and WHEN to transplant, as follows:

In CML:

HSCT: in $1^{\text {st }}$ complete remission - TKI failure, TKI intolerance, acceleration phase, blast crisis:

$\mathrm{TKI} \pm$ chemoinduction is performed

In Myelofibrosis:

HSCT at DIPPS INTERMED 2 and high risk scores at INTERMED 1 and with high risk features

In CMML:

Early HST, pre-treatment with hypomethylating agents

In Mastocytosis:

HSCT: in systemic mastocytosis, AHNMD (SM with associated non-mast cell)

in ASM (Aggressive Systemic Mastocytosis)

in MCL (Mast Cell Leukemia)

\section{Conflict of interest}

No conflict of interest is declared.

\section{References}

1. Passweg JR, Baldomero H, Bader P, Bonini C, Duarte RF, Dufour C, Gennery A, Kröger N, Kuball J, Lanza F, Montoto S, Nagler A, Snowden JA, Styczynski J, Mohty M. Use of haploidentical stem cell transplantation continues to increase: the 2015 European Society for Blood and Marrow Transplant activity survey report. Bone Marrow Transplant. 2017; 52(6):811-817.

2. Hughes TP, Hochhaus A, Branford S, Müller MC, Kaeda JS, Foroni L, Druker BJ, Guilhot F, Larson RA, O’Brien SG, Rudoltz MS, Mone M, Wehrle E, Modur V, Goldman JM, Radich JP; IRIS investigators. Long-term prognostic sig- nificance of early molecular response to imatinib in newly diagnosed chronic myeloid leukemia: an analysis from the International Randomized Study of Interferon and STI571 (IRIS). Blood. 2010;116(19):3758-3765.

3. Saussele S, Lauseker M, Gratwohl A, Beelen D W, Bujes D, Schwerdtfeger R, Kolb H-J, Ho A D, Falge C, Holler E, Schlimok G, Zander A, Arnold R, Kanz L, Dengler R, Haferlach C, Schlegelberger B, Pfirrmann M, Müller M C, Schnittger S, Leitner A, Pletsch N, Hochhaus A, Hasford J, Hehlmann R. Blood. 2010; 115(10): 1880-1885.

4. Hehlmann R, Saußele S, Voskanyan A, Silver RT. Management of CML-blast crisis. Best Pract Res Clin Haematol. 2016; 29(3):295-307.

5. Kongtim P, Adekola K, Milton DR, Ramlal R, Jimenez A, Chen J, Rondon G, Ahmed S, Kebriaei P, Betul O, Hosing CM, Popat U, Khouri I, Jabbour E, Cortes JE, Kantarjian HM, Champlin RE, Ciurea SO. Donor type, in addition to transplantation in chronic phase and myeloablative conditioning, influence transplant survival for patients with advanced chronic myeloid leukemia in the era of tyrosine kinase inhibitors. Leukemia. 2017; 31(7):1654-1657.

6. Rondelli D, Barosi G, Bacigalupo A, Prchal JT, Popat U, Alessandrino EP, Spivak JL, Smith BD, Klingemann HG, Fruchtman S, Hoffman R; Myeloproliferative Diseases-Research Consortium. Allogeneic hematopoietic stem-cell transplantation with reduced-intensity conditioning in intermediate- or high-risk patients with myelofibrosis with myeloid metaplasia. Blood. 2005 May 15; 105(10):4115-4119.

7. Kröger N, Zabelina T, Schieder H, Panse J, Ayuk F, Stute N, Fehse N, Waschke O, Fehse B, Kvasnicka HM, Thiele J, Zander A. Pilot study of reduced-intensity conditioning followed by allogeneic stem cell transplantation from related and unrelated donors in patients with myelofibrosis. Br J Haematol. 2005; 128(5):690-697.

8. Bacigalupo A, Soraru M, Dominietto A, Pozzi S, Geroldi S, Van Lint MT, Ibatici A, Raiola AM, Frassoni F, De Stefano F, Verdiani S, Casarino L, Barosi G. Allogeneic hemopoietic SCT for patients with primary myelofibrosis: a predictive transplant score based on transfusion requirement, spleen size and donor type. Bone Marrow Transplant. 2010; 45(3):458-463. 
9. Kröger N, Holler E, Kobbe G, Bornhäuser M, Schwerdtfeger R, Baurmann H, Nagler A, Bethge W, Stelljes M, Uharek L, Wandt H, Burchert A, Corradini P, Schubert J, Kaufmann M, Dreger P, Wulf GG, Einsele H, Zabelina T, Kvasnicka HM, Thiele J, Brand R, Zander AR, Niederwieser D, de Witte TM. Allogeneic stem cell transplantation after reduced-intensity conditioning in patients with myelofibrosis: a prospective, multicenter study of the Chronic Leukemia Working Party of the European Group for Blood and Marrow Transplantation. Blood. 2009; 114(26):5264-5270.

10. Kröger N, Giorgino T, Scott BL, Ditschkowski M, Alchalby H, Cervantes F, Vannucchi A, Cazzola M, Morra E, Zabelina T, Maffioli M, Pereira A, Beelen D, Deeg HJ, Passamonti F. Impact of allogeneic stem cell transplantation on survival of patients less than 65 years of age with primary myelofibrosis. Blood. 2015; 125(21):3347-3350.

11. Alchalby H, Zabelina T, Stübig T, van Biezen A, Bornhäuser M, Di Bartolomeo P, Beelen D, Cahn JY, Dreger P, Schroyens W, de Witte T, Olavarria E, Kröger N;Chronic Malignancies Working Party of the European Group for Blood and Marrow Transplantation. Allogeneic stem cell transplantation for myelofibrosis with leukemic transformation: a study from the Myeloproliferative Neoplasm Subcommittee of the CMWP of the European Group for Blood and Marrow Transplantation. Biol Blood Marrow Transplant. 2014; 20(2):279-281.

12. Kröger N, Panagiota V, Badbaran A, Zabelina T, Triviai I, Araujo Cruz MM, Shahswar R, Ayuk F, Gehlhaar M, Wolschke C, Bollin R, Walter C, Dugas M, Wiehlmann L, Lehmann U, Koenecke C, Chaturvedi A, Alchalby H, Stadler M, Eder M, Christopeit M, Göhring G, Koenigsmann M, Schlegelberger B, Kreipe HH, Ganser A, Stocking C, Fehse B, Thol F, Heuser M. Impact of Molecular Genetics on Outcome in Myelofibrosis Patients after Allogeneic Stem Cell Transplantation. Biol Blood Marrow Transplant. 2017; 23(7):1095-1101.

13. Klyuchnikov E, Holler E, Bornhäuser M, Kobbe G, Nagler A, Shimoni A, Könecke C, Wolschke C, Bacher U, Zander AR, Kröger N. Donor lymphocyte infusions and second transplantation as salvage treatment for relapsed myelofibrosis after reduced-intensity allografting. Br J Haematol. 2012; 159(2):172-181.

14. Gupta V, Gotlib J, Radich JP, Kröger NM, Rondelli D, Verstovsek S, Deeg HJ. Janus kinase inhibitors and allogeneic stem cell transplantation for myelofibrosis. Biol Blood Marrow Transplant. 2014; 20(9):1274-1281.

15. Kröger N, Kadir S S S A, Zabelina T, Wolschke C, Ayuk F A, Badbaran A, Christopeit M. Ruxolitinib during peritransplant period for myelofrbrosis patients undergoing allogeneic stem cell transplantation reduces acute graft-versushost disease. Blood. 2016; 128: 2242.

16. Liu HD, Ahn KW, Hu ZH, Hamadani M, Nishihori T, Wirk B, Beitinjaneh A, Rizzieri D, Grunwald MR, Sabloff M, Olsson RF, Bajel A, Bredeson C, Daly A, Inamoto Y, Majhail N, Saad A, Gupta V, Gerds A, Malone A, Tallman M, Reshef R, Marks DI, Copelan E, Gergis U, Savoie ML, Ustun C, Litzow MR, Cahn JY, Kindwall-Keller T, Akpek G, Savani
BN, Aljurf M, Rowe JM, Wiernik PH, Hsu JW, Cortes J, Kalaycio M, Maziarz R, Sobecks R, Popat U, Alyea E, Saber W. Allogeneic Hematopoietic Cell Transplantation for Adult Chronic Myelomonocytic Leukemia. Biol Blood Marrow Transplant. 2017; 23(5):767-775.

17. Kongtim P, Popat U, Jimenez A, Gaballa S, El Fakih R, Rondon G, Chen J, Bueso-Ramos C, Borthakur G, Pemmaraju N, Garcia-Manero G, Kantarjian H, Alousi A, Hosing C, Anderlini P, Khouri IF, Kebriaei P, Andersson BS, Oran B, Rezvani K, Marin D, Shpall EJ, Champlin RE, Ciurea SO. Treatment with hypomethylating agents before allogeneic stem cell transplant improves progression-free survival for patients with chronic myelomonocytic leukemia. Biol Blood Marrow Transplant. 2016; 22(1):47-53.

18. Symeonidis A, van Biezen A, de Wreede L, Piciocchi A, Finke J, Beelen D, Bornhäuser M, Cornelissen J, Volin L, Mufti G, Chalandon Y, Ganser A, Bruno B, Niederwieser D, Kobbe G, Schwerdtfeger R, de Witte T, Robin M, Kröger N; Chronic Malignancies Working Party of the European Group for Blood and Marrow Transplantation. Achievement of complete remission predicts outcome of allogeneic haematopoietic stem cell transplantation in patients with chronic myelomonocytic leukaemia. A study of the Chronic Malignancies Working Party of the European Group for Blood and Marrow Transplantation. Br J Haematol. 2015 Jul 26. doi: 10.1111/bjh.13576.

19. Valent P, Sotlar K, Sperr WR, Escribano L, Yavuz S, Reiter A, George TI, Kluin-Nelemans HC, Hermine O, Butterfield JH, Hägglund H, Ustun C, Hornick JL, Triggiani M, Radia D, Akin C, Hartmann K, Gotlib J, Schwartz LB, Verstovsek S, Orfao A, Metcalfe DD, Arock M, Horny HP. Refined diagnostic criteria and classification of mast cell leukemia (MCL) and myelomastocytic leukemia (MML): a consensus proposal. Ann Oncol. 2014; 25(9):1691-700.

20. Ustun C, Reiter A, Scott BL, Nakamura R, Damaj G, Kreil S, Shanley R, Hogan WJ, Perales MA, Shore T, Baurmann H, Stuart R, Gruhn B, Doubek M, Hsu JW, Tholouli E, Gromke T, Godley LA, Pagano L, Gilman A, Wagner EM, Shwayder T, Bornhäuser M, Papadopoulos EB, Böhm A, Vercellotti G, Van Lint MT, Schmid C, Rabitsch W, Pullarkat V, Legrand F, Yakoub-Agha I, Saber W, Barrett J, Hermine O, Hagglund H, Sperr WR, Popat U, Alyea EP, Devine S, Deeg HJ, Weisdorf D, Akin C, Valent P. Hematopoietic stem-cell transplantation for advanced systemic mastocytosis. J Clin Oncol. 2014; 32(29):3264-3274.

21. Jawhar M, Schwaab J, Schnittger S, Meggendorfer M, Pfirrmann M, Sotlar K, Horny H-P, Metzgeroth G, Kluger S, Naumann N, Haferlach C, Haferlach T, Valent P, Hofmann W-K, Fabarius A, Cross N C P, Reiter A. Chronic myleproliferative neoplasms, Additional mutations in SRSF2, ASXL1 and/or RUNX1 identify a high-risk group of patients with KIT D816v+ advanced systemic Mastocytosis. Leukemia. 2016; 30: 136-143.

22. Wang SA, Hasserjian RP, Fox PS, Rogers HJ, Geyer JT, Chabot-Richards D, Weinzierl E, Hatem J, Jaso J, Kanagal-Shamanna R, Stingo FC, Patel KP, Mehrotra M, Bueso-Ramos C, Young KH, Dinardo CD, Verstovsek S, Tiu RV, Bagg A, Hsi ED, Arber DA, Foucar K, Luthra R, Orazi A. 
Atypical chronic myeloid leukemia is clinically distinct from unclassifiable myelodysplastic/myeloproliferative neoplasms. Blood. 2014; 123(17): 2645-2651.

23. Onida F, de Wreede LC, van Biezen A, Eikema DJ, Byrne JL, Iori AP, Schots R, Jungova A, Schetelig J, Finke J, Veelken H, Johansson JE, Craddock C, Stelljes M, Theobald M, Holler E, Schanz U, Schaap N, Bittenbring J, Olavarria E, Chalandon Y, Kröger N. Allogeneic stem cell transplantation in patients with atypical chronic myeloid leukaemia: a retrospective study from the Chronic Malignancies Working Party of the European Society for Blood and Marrow Transplantation. Br J Haematol. 2017; 177(5):759-765.

\title{
| Трансплантация стволовых клеток при миелопроли- феративных заболеваниях в эру молекулярной терапии
}

\author{
Аксель Р. Цандер \\ Онкологический Центр Хантсмана, Университет штата Юта, США
}

\section{Резюме}

Значительная часть аллогенных трансплантаций гемопоэтических стволовых клеток (алло-ТГСК) сейчас проводится по поводу миелодиспластического синдрома или миелопролиферативных заболеваний, тогда как хронический миелоидный лейкоз (ХМЛ) лечат, в основном, ингибиторами тирозинкиназ (ИТК). В некоторых особых ситуациях, есть следующие причины для алло-ТГСК при ХМЛ: токсичность препаратов ИТК, резистентность к обычной лекарственной терапии и прогрессия болезни (фаза акселерации или бластный криз). Однако повышения выживаемости без прогрессии можно добиться в продвинутой фазе ХМЛ после гаплоидентичной ТГСК, по сравнению с пересадкой от HLA-совместимого родственного или неродственного донора.

При планировании терапии первичного миелофиброза (ПМФ) следует учитывать различия в клиническом течении заболевания, применяя, например, Лилльскую систему оценок, которая дает прогностические критерии, а также молекулярно-генетические маркеры, в особенности, гиперэкспрессию гена ЈАК2, что дает основания к применению руксолитиниба. Алло-ТГСК может излечивать болных с ПМФ при трансформации его в лейкоз. В случаях рецидива, вторая алло-ТГСК или инфузия лимофцитов донора может привести к удлинению продолжительности жизни пациентов.
Результаты терапии больных с хроническим миеломоноцитарным лейкозом, леченных алло-ТГСК, зависят от оценок их клинического риска до пересадки. Пациенты, трансплантированные в полной ремиссии, имеют большую длительность общей и безрецидивной выживаемости. Раннее выполнение трансплантации коррелирует с более высокими цифрами выживаемости пациентов. В случаях атипичного ХМЛ следует проводить раннюю трансплантацию. Алло-ТГСК является методом выбора при обширном системном мастоцитозе. Она проводится в случаях, ассоциированных с вовлечением других клеток, кроме мастоцитов, при агрессивном системном мастоцитозе и при мастоцитарной форме лейкоза.

\section{Ключевые слова}

Миелопролиферативные заболевания, аллогенная трансплантация гемопоэтических стволовых клеток, ингибиторы тирозинкиназ, хронический миелоидный лейкоз, первичный миелофиброз, хронический миеломоноцитарный лейкоз, системный мастоцитоз. 